\title{
Effects of Prolonged High Phosphorus Diet on Phosphorus and Calcium Balance in Rats
}

\author{
Yoshiko Tani, Tadatoshi Sato*, Hisami Yamanaka-Okumura, Hironori Yamamoto, \\ Hidekazu Arai, Naoki Sawada, Kaori Genjida, Yutaka Taketani, and Eiji Takeda \\ Department of Clinical Nutrition, Institute of Health Biosciences, The University of Tokushima Graduate School, \\ Tokushima 770-8503, Japan
}

Received 26 October, 2006; Accepted 25 December, 2006

\begin{abstract}
Summary The amount of phosphorus contained in food as food additives is currently increasing and a high intake of phosphorus can cause various diseases. To determine the effects of a prolonged high phosphorus diet, here we investigated the phosphorus and calcium balance and expression of type IIa sodium-dependent phosphate transporter (Npt IIa) in mature rats. Wistar male rats (8-weeks old) were divided into five groups and fed diets containing $0.6 \%$ calcium plus $0.3,0.6,0.9,1.2$ or $1.5 \%$ phosphorus for 4 weeks. Urinary and fecal phosphorus excretions were significantly increased by the high phosphorus diets (from 0.6 to $1.5 \%$ ), dependent on the amount of dietary phosphorus. The net absorption of intestinal phosphorus was also significantly increased by high phosphorus diets. As a result, a negative phosphorus balance was observed in rats given the $1.2 \%$ or $1.5 \%$ phosphorus diets. Serum parathyroid hormone and 1,25-dihydroxyvitamin $D_{3}$ concentrations were increased by high phosphorus diets. In addition, high phosphorus diets decreased the expression of Npt IIa mRNA and protein in the renal brush border membrane. Taken together, these results suggest that diets containing 1.2 or $1.5 \%$ phosphorus plus $0.6 \%$ calcium have potentially adverse effects on phosphorus homeostasis in mature rat.
\end{abstract}

Key Words: high phosphorus diet, mature rat, phosphorus balance, parathyroid hormone (PTH), sodium-dependent phosphate transporter $(\mathrm{Npt})$

\section{Introduction}

Phosphorus additives are used as flavor stabilizers in all popular cola beverages and as chemical additives. Soft drinks and fast food containing a large amount of food additives are a growing feature of current food styles, and the frequency with which we eat fast food has increased markedly since the early 1970s [1]. As a result, this increasing consumption of food containing phosphoric acid can lead to an excess intake

\footnotetext{
*To whom correspondence should be addressed.

Tel: +81-88-633-9595 Fax: +81-88-633-7094

E-mail: tadatoshi@nutr.med.tokushima-u.ac.jp
}

of phosphorus. In addition, a high phosphorus intake has been shown to cause hypocalcemia, hyperphosphatemia, secondary hyperparathyroidism with enhanced bone resorption and bone loss in several animal models $[2,3]$.

Phosphorus balance involves the absorption of dietary phosphorus in the intestine, its distribution in body fluids and tissues, especially bone, and its excretion largely by the kidney. The plasma level of phosphorus is mainly controlled by renal epithelial sodium-dependent phosphorus $(\mathrm{Na} / \mathrm{Pi})$ transporters that are located in the proximal tubules of the kidney [4-6]. Several mammalian renal $\mathrm{Na}^{+}$-dependent $\mathrm{Pi}$ cotransporters have recently been isolated and characterized [4-6]. The cDNAs of these transporters can be divided into three types in the kidney cortex, termed types I-III 
$[5,6]$. Type II Na/Pi cotransporters belong to a unique class of $\mathrm{Na}^{+}$-coupled cotransport proteins and can be further subdivided into three subgroups termed IIa, IIb and IIc [5, 6]. Type IIa and IIc Na/Pi cotransporters (Npt IIa and IIc) are expressed in the proximal tubules of the kidney, whereas type IIb are expressed in several tissues including the lung and small intestine. The functional characteristics, proximal tubular location of their mRNAs, and apical expression of Npt IIa and IIc suggest that these proteins represent the most likely pathway of proximal tubular apical $\mathrm{Na}^{+}$-dependent uptake of phosphorus, although the type IIc cotransporter is a minor component in adults $[5,6]$.

Because increases in serum phosphorus have physiological consequences that could be harmful if sustained over time, we need to give some consideration to the increasing phosphorus content of present-day diets. Studies in rodents have been instrumental in establishing that a high intake of phosphorus, independent of calcium intake, increases bone resorption and reduces bone mass [7-10]. An excess of dietary phosphorus has similar effects in other species including rabbits, pigs, dogs, cats, horses and primates [2,3]. By contrast, phosphorus balance in mature rats remains to be elucidated. Thus, to determine the effects of high phosphorus diets, here we have studied phosphorus and calcium balance and estimated the expression of renal Npt IIa in male mature rats fed the various diets containing from 0.3 to $1.5 \%$ phosphorus.

\section{Materials and Methods}

\section{Experimental design}

Thirty 7-weeks old Wistar male rats were purchased from Clea Japan (Tokyo, Japan) and individually housed in metabolic cages (KN-646B, Natsume Seisakusyo Co., Tokyo, Japan) in a room maintained at $22^{\circ} \mathrm{C}$ with a 12 hour light/ dark cycle (lights on from 8:00 to 20:00). The experimental diets were based on the AIN-93G diet [11], from which five diets containing $0.6 \%$ calcium plus $0.3,0.6,0.9,1.2$, or $1.5 \%$ phosphorus were prepared (Table 1). All rats were fed the $0.3 \%$ phosphorus diet for a 7 -day acclimatization period. After 7 days, the rats were randomly divided into five experimental groups of six rats each and were fed one of the five different phosphorus diets for 4 weeks, respectively. The animals were allowed to eat ad libitum and were given free access to distilled water. On the last 3 days of the experimental period, their urine and feces were collected for analysis. At the end of the experiment, all rats were sacrificed, and blood and kidney samples were collected for analysis.

All animal experiments in the present study were approved by The Committee for the Care and Use of Animals in The University of Tokushima School of Medicine and performed by the Institutional Animal Care and Oversight Committee according to established guideline principles.

Table 1. Composition of the experimental $\operatorname{diet}^{1}$

\begin{tabular}{|c|c|c|c|c|c|}
\hline \multicolumn{6}{|c|}{ Dietary calcium and phosphorus concentration } \\
\hline Calcium $(\%)$ & 0.6 & 0.6 & 0.6 & 0.6 & 0.6 \\
\hline Phosphorus (\%) & $\begin{array}{c}0.3 \\
\text { (control) }\end{array}$ & 0.6 & 0.9 & 1.2 & 1.5 \\
\hline \multicolumn{6}{|l|}{$\mathrm{g} / 100 \mathrm{~g}$ diet } \\
\hline Cornstarch & 39.7486 & 39.7486 & 39.7486 & 39.7486 & 39.7486 \\
\hline Egg white & 20.0000 & 20.0000 & 20.0000 & 20.0000 & 20.0000 \\
\hline Dextrinized cornstarch & 13.2000 & 13.2000 & 13.2000 & 13.2000 & 13.2000 \\
\hline Soybean oil & 7.0000 & 7.0000 & 7.0000 & 7.0000 & 7.0000 \\
\hline Fiber & 5.0000 & 5.0000 & 5.0000 & 5.0000 & 5.0000 \\
\hline Mineral $\mathrm{mix}^{2,3}$ & 1.5645 & 1.5645 & 1.5645 & 1.5645 & 1.5645 \\
\hline Vitamin $\operatorname{mix}^{2}$ & 1.0000 & 1.0000 & 1.0000 & 1.0000 & 1.0000 \\
\hline L-Cyatine & 0.3000 & 0.3000 & 0.3000 & 0.3000 & 0.3000 \\
\hline Choline bitartate & 0.2500 & 0.2500 & 0.2500 & 0.2500 & 0.2500 \\
\hline Tert-butylhydroquinone & 0.0014 & 0.0014 & 0.0014 & 0.0014 & 0.0014 \\
\hline $\mathrm{CaCO}_{3}$ & 1.4984 & 1.4984 & 1.4984 & 1.4984 & 1.4984 \\
\hline $\mathrm{KH}_{2} \mathrm{PO}_{4}$ & 1.2664 & 2.6232 & 3.9800 & 5.3369 & 6.6937 \\
\hline Sucrose & 9.1708 & 7.8139 & 6.4571 & 5.1002 & 3.7435 \\
\hline Total & 100.0 & 100.0 & 100.0 & 100.0 & 100.0 \\
\hline
\end{tabular}




\section{Blood, urine and feces analyses}

The blood samples were centrifuged and the supernatants were used as serum samples. Each urine sample was diluted with $\mathrm{H}_{2} \mathrm{O}$ to adjust the volume to a constant amount. Serum and urine were stored at $-80^{\circ} \mathrm{C}$ until needed for analysis. To measure the calcium and phosphorus contents, the urine and feces were dried, ashed and then demineralized with $1 \mathrm{~mol} / \mathrm{l}$ $\mathrm{HCl}$ solution. Calcium was analyzed by atomic absorption spectrophotometry (Z-8100; Hitachi, Tokyo, Japan) as previously described [12]. Phosphorus was assayed with a Wako Phospha C-test (Wako Pure Chemical Industries, Osaka, Japan). Serum parathyroid hormone (PTH) was assayed with an enzyme-linked immunosorbent assay kit (Immutopics, San Clemente, CA). Serum 1,25(OH) $)_{2} \mathrm{D}_{3}$ was measured with a $1,25(\mathrm{OH})_{2}$ Vitamin D EIA kit (ALPCO Diagnostics, Salem, NH). The amount and the rate of net intestinal absorption of calcium and phosphorus were calculated as follows:

Net absorption $(\mathrm{mg} /$ day $)=$ intake - fecal excretion

Balance $(\mathrm{mg} /$ day $)=$ net absorption - urinary excretion

\section{Isolation of total RNA and northern blot analysis}

Total RNA was isolated from a homogenized kidney by using ISOGEN RNA extraction regent (Nippon Gene, Tokyo, Japan). The amount and purity of the RNA were assessed by spectrophotometry. Samples of total RNA $(20 \mu \mathrm{g})$ from each group of rats were denatured in $10 \mathrm{mmol} / \mathrm{l}$ morpholinopropanesulfonic acid ( $\mathrm{pH} 7.0$ ), $5 \mathrm{mmol} / \mathrm{l}$ sodium acetate, $1 \mathrm{mmol} / 1$ EDTA, $2.2 \mathrm{~mol} / \mathrm{l}$ formaldehyde, and 50\% formamide at $65^{\circ} \mathrm{C}$ for $15 \mathrm{~min}$, separated by electrophoresis through a $1.2 \%$ agarose $/ 2.2 \mathrm{mmol} / 1$ formaldehyde gel, and transferred to a nylon membrane (Hybond-N, Amersham pharmacia biotech, Piscataway, NJ). The membrane was airdried and the RNA samples were crosslinked to the nylon membrane by UV irradiation. Migration of $28 \mathrm{~S}$ and $18 \mathrm{~S}$ ribosomal RNA was determined by ethidium bromide staining. Rat Npt IIa (GeneBank accession number, NM_013030; sense primer 5'-GAGCTCCGCCATTCCGATAA-3', antisense primer 5'-AAAGGGTGTGCCCACACCGA-3', nucleotides +543 to +1639 relative to the translation start site) [13] and rat GAPDH (GeneBank accession number, NM_017008; sense primer 5'-CCAGTATGACTCTACCCACGGC-3', antisense primer 5'-GAAGGCCATGCCAGTGAGCTTC-3', +135 to +693 relative to the translation start site) cDNA probes were prepared by polymerase chain reaction using kidney total cDNA and specific oligonucleotide primers. The PCR conditions were: an initial $2 \mathrm{~min}$ denaturation at $95^{\circ} \mathrm{C}$, followed by 35 cycles of $60 \mathrm{sec}$ at $60^{\circ} \mathrm{C}, 40 \mathrm{sec}$ at $94^{\circ} \mathrm{C}$, and a final $7 \mathrm{~min}$ extension at $72^{\circ} \mathrm{C}$. Each probe was radiolabeled with [ $\alpha-32 \mathrm{P}]$-dCTP (9.25 MBq/mmol; Amersham pharmacia biotech, Piscataway, NJ) by using a random-primer DNA labeling kit (Takara, Tokyo, Japan). Prehybridization was carried out for $3-4 \mathrm{~h}$ at $42^{\circ} \mathrm{C}$ with a prehybridization buffer containing $50 \%$ formamide, $40 \mathrm{mmol} / 1$ Tris $/ \mathrm{HCl}(\mathrm{pH} 7.5)$, $1 \%$ SDS, $10 \times$ Denhardt's solution, $10 \mathrm{mg} / \mathrm{ml}$ salmon sperm DNA and $0.01 \mathrm{~mol} / 1$ EDTA. The labeled probe was then added to the prehybidization buffer, and the membrane was incubated overnight $(16-18 \mathrm{~h})$ at $42^{\circ} \mathrm{C}$. The membrane was washed first for $30 \mathrm{~min}$ at $42^{\circ} \mathrm{C}$ in a buffer containing $0.1 \times \mathrm{SSC}(\mathrm{SSC}$ is $0.15 \mathrm{mmol} / 1 \mathrm{NaCl}, 0.015 \mathrm{mmol} / 1$ sodium citrate) and $0.1 \% \mathrm{SDS}$, and then for $30 \mathrm{~min}$ at $65^{\circ} \mathrm{C}$ in the same buffer. The relative abundance of $\mathrm{Npt}$ IIa and glyceraldehyde-3-phosphate dehydrogenase (GAPDH) was quantitatively determined by a BAS1500 system (Fuji Photo Film, Tokyo, Japan). Each result is expressed as the ratio of Npt IIa mRNA to GAPDH mRNA.

\section{Immunoblotting analysis}

Brush-border membrane vesicles (BBMVs) were prepared from rat kidney by the $\mathrm{Ca}^{2+}$ precipitation method as described previously [14]. The levels of leucine aminopeptidase, $\mathrm{Na}^{+} \mathrm{K}^{+}$ATPase, and cytocrome $c$ oxidase were measured to assess the purity of the membranes. The procedure is based on the principle that leucine aminopeptidase cleaves a substrate Lleucyl- $\beta$-naphthylamide to leucine $+\beta$-naphthylamide, which can be measured spectrophotometrically. To confirm the preparation of BBMVs, leucine aminopeptidase activity was assessed and detected. $\mathrm{Na}^{+} \mathrm{K}^{+}$-ATPase as the basolateral membrane marker and cytocrome $c$ as the mitochondrial marker were not detectable by the method of Scharschmidt et al. [15] and Beaufay et al. [16], respectively. These results indicate that BBMVs would be enriched in the preparation and it can be utilized for further analyses in this study. Protein samples were heated at $95^{\circ} \mathrm{C}$ for $5 \mathrm{~min}$ in sample buffer in 5\% 2-mercaptoethanol and subjected to SDSpolyacrylamide gel electrophoresis. The separated proteins were transferred electrophoretically on Hybond-P polybinylidene deifluoride transger membranes (Amersham pharmacia biotech, Piscataway, NJ). The membranes were incubated with diluted affinity-purified anti-Npt IIa (1:4000) or $\beta$-actin (1:5000) antibody, and then with horseradish peroxidase-conjugated anti-rabbit or -mouse $\operatorname{IgG}$ as the secondary antibody (Jackson ImmunoResearch Laboratories, Inc., West Grove, PA), respectively. The signals were detected using an ECL Plus system (Amersham pharmacia biotech, Piscataway, NJ).

\section{Anti-peptide antibody}

Oligopeptides LALPAHHNATRL (corresponding to residues 321-331 of the rat Npt IIa) were synthesized [14]. Mouse monoclonal anti- $\beta$-actin antibody (Cat. No. A5411) was purchased from sigma.

\section{Statistical analyses}

Date are presented as the mean \pm SEM for each group of six rats. Normally distributed variables were compared by 
the Student's $t$ test and non-normally distributed variables by the Mann-Whitney $U$ test. Differences are considered significant for a $p$ value of less than 0.05 . Statistical analyses were performed by Stat View 5 software (SAS Institute, Cary, NC).

\section{Results}

Relationship between dietary phosphorus intake and body weight gain

To determine the effects of the excess dietary phosphorus on mature rats, we administered five diets containing 0.3 , $0.6,0.9,1.2$ or $1.5 \%$ phosphorus to 8 -weeks old Wistar male rats for 4 weeks. Food intake was decreased in rat given the high phosphorus diets (containing 0.6 to $1.5 \%$ phosphorus) as compared with the control diet $(0.3 \%$ phosphorus) group (Table 2). The high phosphorus diets tended to induce a decrease in body weight gain ( $\mathrm{g} / 4$ weeks). In addition, the $1.5 \%$ phosphorus diet significantly affected body weight gain per $100 \mathrm{~g}$ of intake as compared with the control diet.

Serum concentration of calcium, phosphorus, PTH and $1,25(\mathrm{OH})_{2} \mathrm{D}_{3}$

The high phosphorus diets slightly increased the serum phosphorus concentration and did not changed the serum calcium concentration (Table 3). Serum PTH and
$1,25(\mathrm{OH})_{2} \mathrm{D}_{3}$ concentrations were increased in rats given the high phosphorus diets. In particular, the $1.5 \%$ phosphorus diet increased the serum PTH concentration 9.6-fold as compared with the control group.

\section{Effects of high phosphorus diets on phosphorus and calcium balance}

The high phosphorus diets significantly increased the amount of phosphorus intake by the rats (Table 4). Urinary and fecal phosphorus excretions were significantly increased by the high phosphorus diets, dependent on the amount of dietary phosphorus. In particular, urinary phosphorus excretion was increased approximately 65.5 -fold in rats given the $1.5 \%$ phosphorus diet as compared with the control diet. Intestinal net phosphorus absorption was also significantly increased by the high phosphorus diets, dependent on the amount of dietary phosphorus. In addition, a negative phosphorus balance was observed in rats given the 1.2 or $1.5 \%$ phosphorus diet. The intake amount of calcium tended to be lower in rats given the $1.5 \%$ phosphorus diet than in those fed the control diet. Urinary calcium excretion was decreased in the high phosphorus diets groups. Fecal calcium excretion was not affected by dietary phosphorus intake. Intestinal net calcium absorption was significantly decreased in rats given the $1.5 \%$ high phosphorus diet as compared with the control diet. On the other hand, a positive calcium balance was

Table 2. Food intake and body weight gain in rats fed high phosphorus diets ${ }^{1}$

\begin{tabular}{|c|c|c|c|c|c|}
\hline \multicolumn{6}{|c|}{ Dietary calcium and phosphorus concentration } \\
\hline Calcium $(\%)$ & 0.6 & 0.6 & 0.6 & 0.6 & 0.6 \\
\hline Phosphorus (\%) & 0.3 & 0.6 & 0.9 & 1.2 & 1.5 \\
\hline Intake $(g / 4 w)$ & $507.9 \pm 13.9$ & $453.8 \pm 15.6^{*, 2}$ & $451.1 \pm 13.4^{*}$ & $467.0 \pm 7.1^{*}$ & $421.4 \pm 4.6^{* *}$ \\
\hline Body weight gain $(\mathrm{g} / 4 \mathrm{w})$ & $95.0 \pm 5.1$ & $82.3 \pm 0.9$ & $73.3 \pm 4.4^{* *}$ & $84.0 \pm 4.4$ & $58.7 \pm 6.0^{* * *}$ \\
\hline Body weight gain/100 g intake & $18.78 \pm 1.24$ & $18.21 \pm 0.48$ & $16.21 \pm 0.63$ & $18.01 \pm 1.14$ & $13.88 \pm 1.3^{*}$ \\
\hline
\end{tabular}

${ }^{1}$ Results are expressed as the mean $\pm \operatorname{SEM}(n=6)$ in each phosphorus diet group.

${ }^{2}$ Significantly different from those of the $0.3 \%$ phosphorus diet group $\left({ }^{*} p<0.05 ;{ }^{* *} p<0.01 ; * * * p<0.001\right)$.

Rats were randomly divided into five experimental groups and fed one of the five different phosphorus diets for 4 weeks. Intake and body weight were measured twice a week.

Table 3. Serum concentration of calcium, phosphorus, parathyroid hormone and 1,25-dihydroxyvitamin $\mathrm{D}_{3}{ }^{1}$

\begin{tabular}{|c|c|c|c|c|c|}
\hline \multicolumn{6}{|c|}{ Dietary calcium and phosphorus concentration } \\
\hline Calcium $(\%)$ & 0.6 & 0.6 & 0.6 & 0.6 & 0.6 \\
\hline Phosphorus (\%) & 0.3 & 0.6 & 0.9 & 1.2 & 1.5 \\
\hline Calcium (mg/dl) & $10.95 \pm 0.56$ & $10.38 \pm 0.33$ & $11.39 \pm 0.69$ & $10.95 \pm 0.32$ & $10.72 \pm 0.41$ \\
\hline Phosphorus (mg/dl) & $7.52 \pm 0.74$ & $8.13 \pm 0.32$ & $7.83 \pm 0.46$ & $8.52 \pm 0.85$ & $9.39 \pm 1.71$ \\
\hline PTH (pg/ml) & $7.82 \pm 3.81$ & $33.76 \pm 11.43$ & $32.53 \pm 19.48$ & $25.06 \pm 10.35$ & $75.12 \pm 0.28 * * *, 2$ \\
\hline $1,25(\mathrm{OH})_{2} \mathrm{D}_{3}(\mathrm{pg} / \mathrm{ml})$ & $65.4 \pm 4.7$ & $102.6 \pm 25.9$ & $115.8 \pm 12.4^{* *}$ & $124.9 \pm 51.4$ & $112.3 \pm 19.0$ \\
\hline
\end{tabular}

\footnotetext{
${ }^{1}$ Results are expressed as the mean $\pm \operatorname{SEM}(n=6)$ in each phosphorus diet group.

${ }^{2}$ Significantly different from those of the $0.3 \%$ phosphorus diet group $\left({ }^{*} p<0.05 ; * * p<0.01 ; * * * p<0.001\right)$.

$\mathrm{PTH}$, parathyroid hormone; $1,25(\mathrm{OH})_{2} \mathrm{D}_{3}$, 1,25-dihydroxyvitamin $\mathrm{D}_{3}$.
} 
Table 4. Phosphorus and calcium balance and net absorption after different dietary phosphorus intake

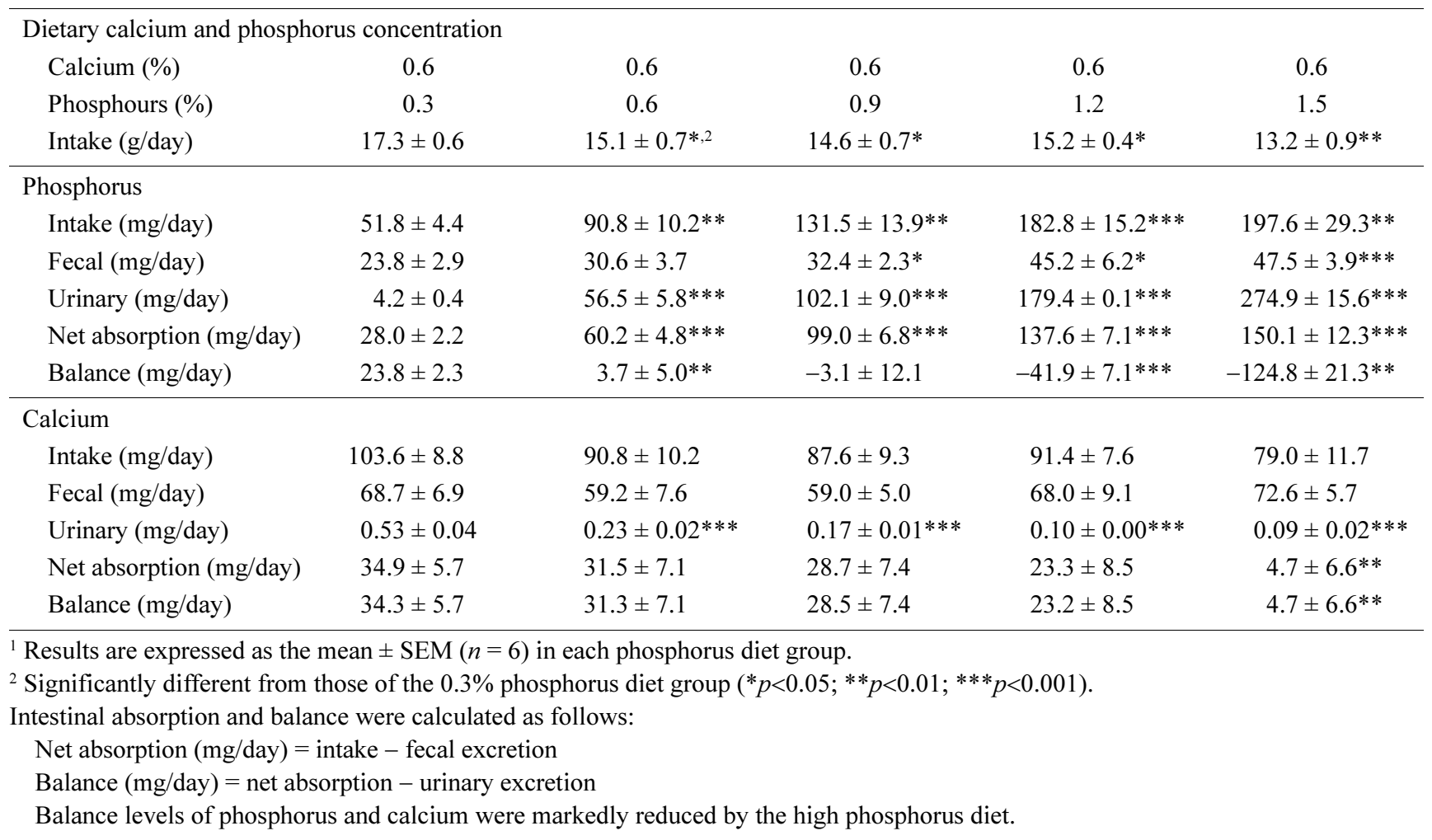

observed in rats given the $1.5 \%$ phosphorus diet, whereas the phosphorus balance was negative in rats fed the high phosphorus diets.

Effects of dietary phosphorus intake on the expression of renal Npt IIa

Npt IIa mRNA, detected as a 2.6-kb transcript, was decreased in the kidney of rats given the high phosphorus diets (Fig. 1). The amount of Npt IIa mRNA in the $1.5 \%$ phosphorus diet group was decreased to $57 \%$ of that in the control diet group. Moreover, the amount of Npt IIa protein in the $1.5 \%$ phosphorus diet group decreased to $21 \%$ of that in the control group (Fig. 2). In addition, the reduction in $\mathrm{Npt}$ IIa protein tended to parallel the increases in dietary phosphorus intake.

\section{Discussion}

The amount of phosphorus contained in food as food additives is continually increasing [17, 18]. A high phosphorus intake causes hypocalcemia, hyperphosphataemia, secondary hyperparathyroidism with bone resorption and bone loss [2, $3,19,20]$. In previous studies, many experiments have estimated the phosphorus balance in young and older rats [21-25]. However, the effect of high dietary phosphorus on phosphorus balance in mature rats is not well understood. To determine the effects of high phosphorus diets in the long- term, we studied phosphorus and calcium balance in mature rats fed diets containing from 0.3 to $1.5 \%$ phosphorus. We found that the high phosphorus diets significantly increased urinary phosphorus excretion in mature rats as compared with the control diet (Table 4). It has been reported that urinary phosphorus and fecal phosphorus excretion increases significantly in weaning and adolescent rats with a high phosphorus intake $[22,26,27]$. In our study, intestinal phosphorus absorption and urinary phosphorus excretion were also significantly increased with higher intakes of phosphorus. In particular, mature rats fed the 1.2 or $1.5 \%$ phosphate diet for 4 weeks showed a significant decline to give a negative phosphorus balance (Table 4). More specifically, urinary phosphorus excretion increased above intestinal phosphorus absorption in rats given the 1.2 or $1.5 \%$ phosphorus diet. These results suggest that a reduction in renal phosphorus reabsorption, leading to excess of phosphorus excretion, was responsible for the negative phosphorus balance observed in mature rats exposed to prolonged excess dietary phosphorus.

The primary regulation of phosphorus balance occurs at the kidney through the Npt IIa transporter, which is responsible for phosphate reabsorption, in the brush border membrane of proximal tubules [4-6]. Expression of Npt IIa is regulated by many factors involved in phosphorus homeostasis, such as PTH [28, 29] and dietary phosphorus [30, 31]. Our results indicated that rat $\mathrm{Npt}$ IIa mRNA expression and protein 
(A) Dietary phosphorus concentration (\%)
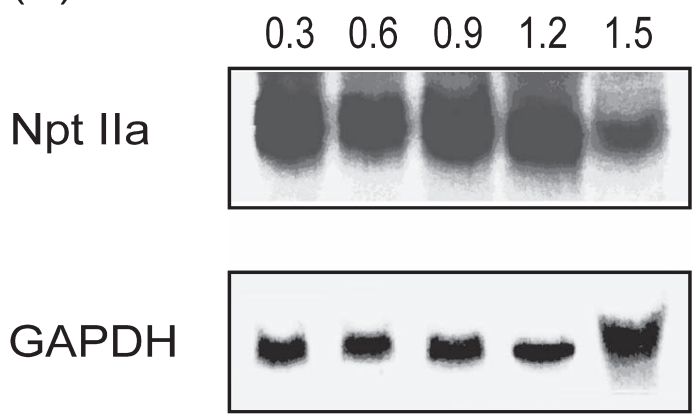

(B)

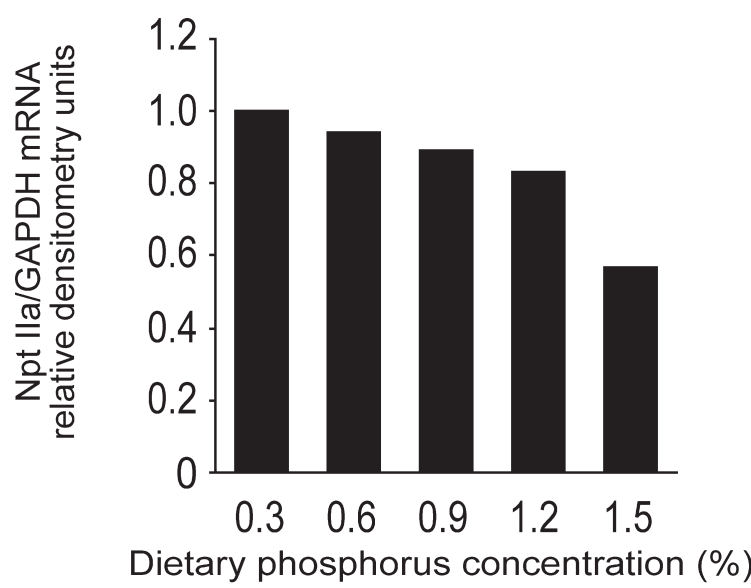

Fig. 1. Amount of renal Npt IIa mRNA in rats fed high phosphorus diets. Mature rats were fed a 0.3, 0.6, 0.9, 1.2 or $1.5 \%$ phosphorus diet for 4 weeks. The composition of each diet is listed in Table 1. Total RNA extracted from the kidney of these rats was subjected to northern blot analysis, as described in Materials and Methods (A). The amount of Npt IIa mRNA was normalized to the amount of the internal standard (GAPDH) mRNA and then expressed as ratio of the value obtained for the $0.3 \%$ phosphorus diet $(\mathrm{B})$.

abundance were reduced with increasing concentrations of dietary phosphorus (Figs. 1 and 2). At the same time, serum PTH concentration was significantly increased in rats given the high phosphorus diets (Table 3). Previous studies have reported that high phosphorus diets directly stimulate PTH secretion [32]. Furthermore, a chronic excess of dietary phosphorus intake and PTH secretion decrease renal phosphate reabsorption by endocytotic internalization of Npt IIa protein in the brush border membrane with transcriptional regulation $[28,29]$. Thus, these results suggest that the increase in urinary phosphorus excretion was due to a decrease in Npt IIa protein.

In a recent report, fibroblast growth factor-23 (FGF-23) has been implicated in the physiological regulation of phosphorus homeostasis independent of PTH, in particular,
(A)

Dietary phosphorus concentration (\%)

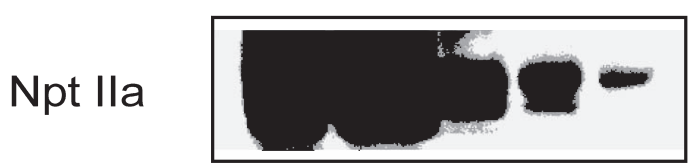

$\beta$-actin

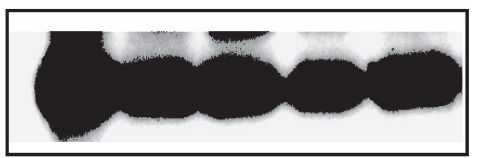

(B)

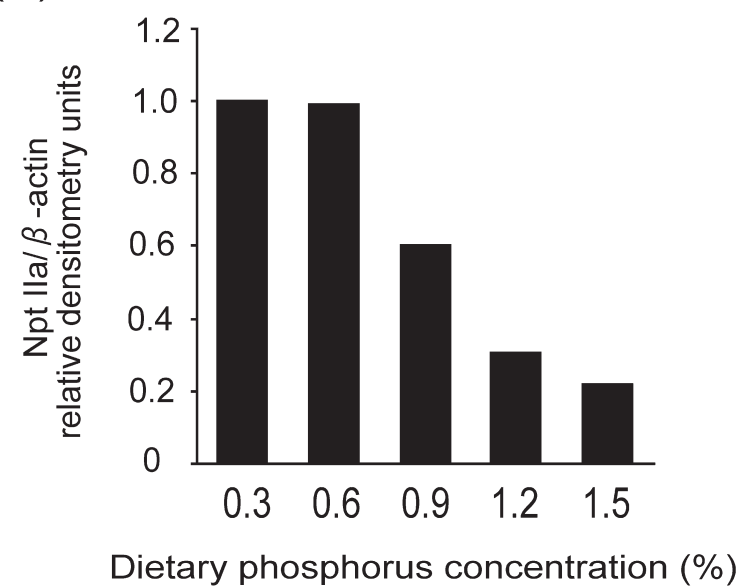

Fig. 2. Amount of renal Npt IIa proteins in rats fed high phosphorus diets. Mature rats were fed a 0.3, 0.6, 0.9, 1.2 or $1.5 \%$ phosphorus diet for 4 weeks. The composition of each diet is listed in Table 1. Immunoblotting analysis of rat Npt IIa protein in the brush border membrane vesicles (BBMVs) of the rat renal cortex was performed, as described in Materials and Methods (A). The amount of Npt IIa protein in BBMVs was normalized to the amount of the internal standard ( $\beta$-actin) protein and then expressed as ratio of the value obtained for the $0.3 \%$ phosphorus diet (B).

in response to dietary phosphorus load [33]. Here, we found that Npt IIa protein decreased in parallel with increasing of dietary phosphorus intake; however, the serum PTH concentration was not changed by the middle range of phosphorus diets (0.6 to $1.2 \%)$. Therefore, one of the phosphorus regulating factors, including FGF-23, may partly assist in PTH-mediated regulation of Npt IIa expression.

On the other hand, we found that high phosphorus diets increased the serum PTH concentration. In the previous studies, nutritional secondary hyperparathyroidism also occurs in rats fed a high phosphorus diet [34], which induced by parathyroid cell proliferation [35] and secretion [36]. Hyperparathyroidism has been linked to progressive bone loss in a number of species [18]. In cell cultures, inorganic phosphate causes osteoblast apoptosis [37]. Increased 
osteoblast apoptosis reduces bone formation and increases fracture risk [38]. Experiments with aging mice and rats show that excess dietary phosphorus accelerates bone resorption [8, 39]. Furthermore, previous studies have shown that a high phosphorus diet induces extensive PTHdependent nephrocalcinosis [34, 40]. These findings suggested that the various organs might be affected by nutritional secondary hyperparathyroidism in rats fed, especially, the 1.2 or $1.5 \%$ phosphate diet.

In our study, food intake and body weight gain were decreased by the high phosphorus diets; in particular, the $1.5 \%$ phosphorus diet significantly affected body weight (Table 2). Previous studies also indicate that food intake and body weight gain decrease when young and old rats are fed high phosphorus diets [26, 27, 41]. In contrast, Landsman et al. reported that $0.02-0.04 \%$ low phosphorus diets decreased food intake and body weight in 5-weeks old male rat, and then phosphorus addition led to an immediate increment in body weight associated with an equally rapid effect on food intake [42]. Therefore, the concentration of dietary phosphorus exerts a real effect, either directly or indirectly, on appetite [43]. Taken together, these results suggest that a high phosphorus diets is important for food intake and body weight gain; however, further studies are necessary to elucidate this hypothesis.

In conclusion, the Npt IIa transporter, which mainly regulates phosphorus balance, was decreased by prolonged high phosphorus diets in mature rats. This decrease could, at least in part, be due to an increase in PTH caused by phosphorus intake, but other mechanisms cannot be ruled out. Consequently, a negative phosphorus balance was observed in rats given the 1.2 or $1.5 \%$ phosphorus diet. Therefore, the present study highlights a potentially adverse effect of phosphorus homeostasis in rats given diets containing 1.2 or $1.5 \%$ phosphorus plus $0.6 \%$ calcium. Further studies to determine the upper safe limit of dietary phosphorus are warranted.

\section{Acknowledgments}

This work was supported by a Grant-in Aid for Scientific Research (10557096) from the Ministry of Education, Science, and Culture, grant from the Setsuro Fujii Memorial Foundation (to E. Takeda), and Knowledge Cluster Initiative from Ministry of Education, Science and Technology.

\section{References}

[1] French, S.A., Harnack, L., and Jeffery, R.W.: Fast food restaurant use among women in the Pound of Prevention study: dietary, behavioral and demographic correlates. Int. J. Obes. Relat. Metab. Disord., 24, 1353-1359, 2000.

[2] Calvo, M.S. and Park, Y.K.: Changing phosphorus content of the U.S. diet: potential for adverse effects on bone. J. Nutr., 126, 1168S-1180S, 1996.

[3] Calvo, M.S.: The effects of high phosphorus intake on calcium homeostasis, in Advances in Nutritional Research, ed. By Draper, H., Plenum Press, New York, pp. 183-207, 1994.

[4] Takeda, E., Taketani, Y., Morita, K., Tatsumi, S., Katai, K., Nii, T., Yamamoto, H., and Miyamoto, K.: Molecular mechanisms of mammalian inorganic phosphate homeostasis. Adv. Enzyme Regul., 40, 285-302, 2000.

[5] Takeda, E., Yamamoto, H., Nashiki, K., Sato, T., Arai, H., and Taketani, Y.: Inorganic phosphate homeostasis and the role of dietary phosphorus. J. Cell Mol. Med., 8, 191-200, 2004.

[6] Miyamoto, K., Segawa, H., Ito, M., and Kuwahata, M.: Physiological regulation of renal sodium-dependent phosphate cotransporters. Jpn. J. Physiol., 54, 93-102, 2004.

[7] Clark, I.: Importance of dietary $\mathrm{Ca}: \mathrm{PO}_{4}$ ratios on skeletal, $\mathrm{Ca}$, $\mathrm{Mg}$, and $\mathrm{PO}_{4}$ metabolism. Am. J. Physiol., 217, 865-870, 1969.

[8] Draper, H.H., Sie, T.L., and Bergan, J.G.: Osteoporosis in aging rats induced by high phosphorus diets. J. Nutr., 102, 1133-1141, 1972.

[9] Shah, B.G., Krishnarao, G.V., and Draper, H.H.: The relationship of $\mathrm{Ca}$ and $\mathrm{P}$ nutrition during adult life and osteoporosis in aged mice. J. Nutr., 92, 30-42, 1967.

[10] Sie, T.L., Draper, H.H., and Bell, R.R.: Hypocalcemia, hyperparathyroidism and bone resorption in rats induced by dietary phosphate. J. Nutr., 104, 1195-1201, 1974.

[11] Reeves, P.G., Nielsen, F.H., and Fahey, G.C. Jr.: AIN-93 purified diets for laboratory rodents: final report of the American Institute of Nutrition ad hoc writing committee on the reformulation of the AIN-76A rodent diet. J. Nutr., 123, 1939-1951, 1993.

[12] Sato, T., Yamamoto, H., Sawada, N., Nashiki, K., Tsuji, M., Nikawa, T., Arai, H., Morita, K., Taketani, Y., and Takeda, E.: Immobilization decreases duodenal calcium absorption through a 1,25-dihydroxyvitamin D-dependent pathway. $J$. Bone Miner. Metab., 24, 291-299, 2006.

[13] Magagnin, S., Werner, A., Markovich, D., Sorribas, V., Stange, G., Biber, J., and Murer, H.: Expression cloning of human and rat renal cortex $\mathrm{Na} / \mathrm{Pi}$ cotransport. Proc. Natl. Acad. Sci. US A, 90, 5979-5983, 1993.

[14] Katai, K., Segawa, H., Haga, H., Morita, K., Arai, H., Tatsumi, S., Taketani, Y., Miyamoto, K., Hisano, S., Fukui, Y., and Takeda, E.: Acute regulation by dietary phosphate of the sodium-dependent phosphate transporter $(\mathrm{NaP}(\mathrm{i})-2)$ in rat kidney. J. Biochem., 121, 50-55, 1997.

[15] Scharschmidt, B.F., Keeffe, E.B., Blankenship, N.M., and Ockner, R.K.: Validation of a recording spectrophotometric method for measurement of membrane-associated Mg- and NaK-ATPase activity. J. Lab. Clin. Med., 93, 790-799, 1979.

[16] Beaufay, H., Amar-Costesec, A., Feytmans, E., Thines-Sempoux, D., Wibo, M., Robbi, M., and Berthet, J.: Analytical study of microsomes and isolated subcellular membranes from rat liver. I. Biochemical methods. J. Cell. Biol., 61, 188-200, 1974.

[17] Takeda, E., Sakamoto, K., Yokota, K., Shinohara, M., Taketani, 
Y., Morita, K., Yamamoto, H., Miyamoto, K., and Shibayama, M.: Phosphorus supply per capita from food in Japan between 1960 and 1995. J. Nutr. Sci. Vitaminol., 48, 102108, 2002.

[18] Calvo, M.S.: Dietary phosphorus, calcium metabolism and bone. J. Nutr., 123, 1627-1633, 1993.

[19] Lutwak, L.: Metabolic and biochemical considerations of bone. Ann. Clin. Lab. Sci., 5, 185-194, 1975.

[20] Draper, H.H. and Bell, R.R.: Nutrition and osteoporsis, in Advances in Nutritional Research, ed. By Draper, H., Plenum Press, New York, pp. 79-106, 1979.

[21] Howe, J.C. and Beecher, G.R.: Effect of dietary protein and phosphorus levels on calcium and phosphorus metabolism of the young, fast growing rat. J. Nutr., 111, 708-720, 1981.

[22] Shah, B.G. and Meranger, J.C.: Effect of increased dietary phosphorus on calcium metabolism of young rats. Can. J. Physiol. Pharmacol., 48, 675-680, 1970.

[23] Armbrecht, H.J., Gross, C.J., and Zenser, T.V.: Effect of dietary calcium and phosphorus restriction on calcium and phosphorus balance in young and old rats. Arch. Biochem. Biophys., 210, 179-185, 1981.

[24] Young, C.M., Empey, E.L., Turk, D., and Serraon, V.U.: Experimental obesity and weight reduction in young female rats: development of procedures and calcium and phosphorus balance studies. J. Nutr., 70, 353-360, 1960.

[25] Yeh, J.K., Aloia, J.F., and Yasumura, S.: Effect of physical activity on calcium and phosphorus metabolism in the rat. Am. J. Physiol., 256, E1-6, 1989.

[26] Katsumata, S., Masuyama, R., Uehara, M., and Suzuki, K.: Decreased mRNA expression of the PTH/PTHrP receptor and type II sodium-dependent phosphate transporter in the kidney of rats fed a high phosphorus diet accompanied with a decrease in serum calcium concentration. Biosci. Biotechnol. Biochem., 68, 2484-2489, 2004.

[27] Karlen, J.: Renal response to low and high phosphate intake in weanling, adolescent and adult rats. Acta. Physiol. Scand., 135, 317-322, 1989.

[28] Kempson, S.A., Lotscher, M., Kaissling, B., Biber, J., Murer, H., and Levi, M.: Parathyroid hormone action on phosphate transporter mRNA and protein in rat renal proximal tubules. Am. J. Physiol., 268, F784-791, 1995.

[29] Lotscher, M., Scarpetta, Y., Levi, M., Halaihel, N., Wang, H., Zajicek, H.K., Biber, J., Murer, H., and Kaissling, B.: Rapid downregulation of rat renal $\mathrm{Na} / \mathrm{P}(\mathrm{i})$ cotransporter in response to parathyroid hormone involves microtubule rearrangement. J. Clin. Invest., 104, 483-494, 1999.

[30] Ritthaler, T., Traebert, M., Lotscher, M., Biber, J., Murer, H., and Kaissling, B.: Effects of phosphate intake on distribution of type II Na/Pi cotransporter mRNA in rat kidney. Kidney Int., 55, 976-983, 1999.

[31] Takahashi, F., Morita, K., Katai, K., Segawa, H., Fujioka, A.,
Kouda, T., Tatsumi, S., Nii, T., Taketani, Y., Haga, H., Hisano, S., Fukui, Y., Miyamoto, K., and Takeda, E.: Effects of dietary $\mathrm{Pi}$ on the renal $\mathrm{Na}+$-dependent $\mathrm{Pi}$ transporter $\mathrm{NaPi}$ 2 in thyroparathyroidectomized rats. Biochem. J., 333, 175$181,1998$.

[32] Hernandez, A., Concepcion, M.T., Rodriguez, M., Salido, E., and Torres, A.: High phosphorus diet increases preproPTH mRNA independent of calcium and calcitriol in normal rats. Kidney Int., 50, 1872-1878, 1996.

[33] Ferrari, S.L., Bonjour, J.P., and Rizzoli, R.: Fibroblast growth factor-23 relationship to dietary phosphate and renal phosphate handling in healthy young men. J. Clin. Endocrinol. Metab., 90, 1519-1524, 2005.

[34] Clark, I. and Rivera-Cordero, F.: Prevention of phosphateinduced nephrocalcinosis by parathyroidectomy. Proc. Soc. Exp. Biol. Med., 139, 803-805, 1972.

[35] Roussanne, M.C., Lieberherr, M., Souberbielle, J.C., Sarfati, E., Drueke, T., and Bourdeau, A.: Human parathyroid cell proliferation in response to calcium, NPS R-467, calcitriol and phosphate. Eur. J. Clin. Invest., 31, 610-616, 2001.

[36] Karkkainen, M. and Lamberg-Allardt, C.: An acute intake of phosphate increases parathyroid hormone secretion and inhibits bone formation in young women. J. Bone Miner. Res., 11, 1905-1912, 1996.

[37] Meleti, Z., Shapiro, I.M., and Adams, C.S.: Inorganic phosphate induces apoptosis of osteoblast-like cells in culture. Bone, 27, 359-366, 2000.

[38] O’Brien, C.A., Jia, D., Plotkin, L.I., Bellido, T., Powers, C.C., Stewart, S.A., Manolagas, S.C., and Weinstein R.S.: Glucocorticoids act directly on osteoblasts and osteocytes to induce their apoptosis and reduce bone formation and strength. Endocrinology, 145, 1835-1841, 2004.

[39] Huttunen, M.M., Pietila, P.E., Viljakainen, H.T., and LambergAllardt, C.J.: Prolonged increase in dietary phosphate intake alters bone mineralization in adult male rats. J. Nutr. Biochem., 17, 479-484, 2006.

[40] Borle, A.B. and Clark, I.: Effects of phosphate-induced hyperparathyroidism and parathyroidectomy on rat kidney calcium in vivo. Am. J. Physiol., 241, E136-141, 1981.

[41] Katsumata, S., Matsuzaki, H., Uehara, M., and Suzuki, K.: Effects of lowering food intake by high phosphorus diet on parathyroid hormone actions and kidney mineral concentration in rats. Biosci. Biotechnol. Biochem., 70, 528-531, 2006.

[42] Landsman, A., Lichtstein, D., Bacaner, M., and Ilani, A.: Dietary phosphate-dependent growth is not mediated by changes in plasma phosphate concentration. Br. J. Nutr., 86, 217-223, 2001.

[43] Landsman, A., Lichtstein, D., and Ilani, A.: Distinctive features of dietary phosphate supply. J. Appl. Physiol., 99, 1214-1219, 2005. 